\title{
Gold Reselling in Online Transaction: A Study from Muamalat Perspective
}

Muhammad Saiful Islam Ismail, Syaimak Ismail, Aemy Aziz, Muhammad Anas Ibrahim, \& Mohd Khairi Ismail

To Link this Article: http://dx.doi.org/10.6007/IJARBSS/v11-i6/10175

DOI:10.6007/IJARBSS/v11-i6/10175

Received: 05 April 2021, Revised: 07 May 2021, Accepted: 28 May 2021

Published Online: 13 June 2021

In-Text Citation: (Ismail et al., 2021)

To Cite this Article: Ismail, M. S. I., Ismail, S., Aziz, A., Ibrahim, M. A., \& Ismail, M. K. (2021). Gold Reselling in Online Transaction: A Study from Muamalat Perspective. International Journal of Academic Research in Business and Social Sciences, 11(6), 488-496.

\section{Copyright: (c) 2021 The Author(s)}

Published by Human Resource Management Academic Research Society (www.hrmars.com)

This article is published under the Creative Commons Attribution (CC BY 4.0) license. Anyone may reproduce, distribute, translate and create derivative works of this article (for both commercial and non-commercial purposes), subject to full attribution to the original publication and authors. The full terms of this license may be seen at: http://creativecommons.org/licences/by/4.0/legalcode

Vol. 11, No. 6, 2021, Pg. 488 - 496

Full Terms \& Conditions of access and use can be found at http://hrmars.com/index.php/pages/detail/publication-ethics 


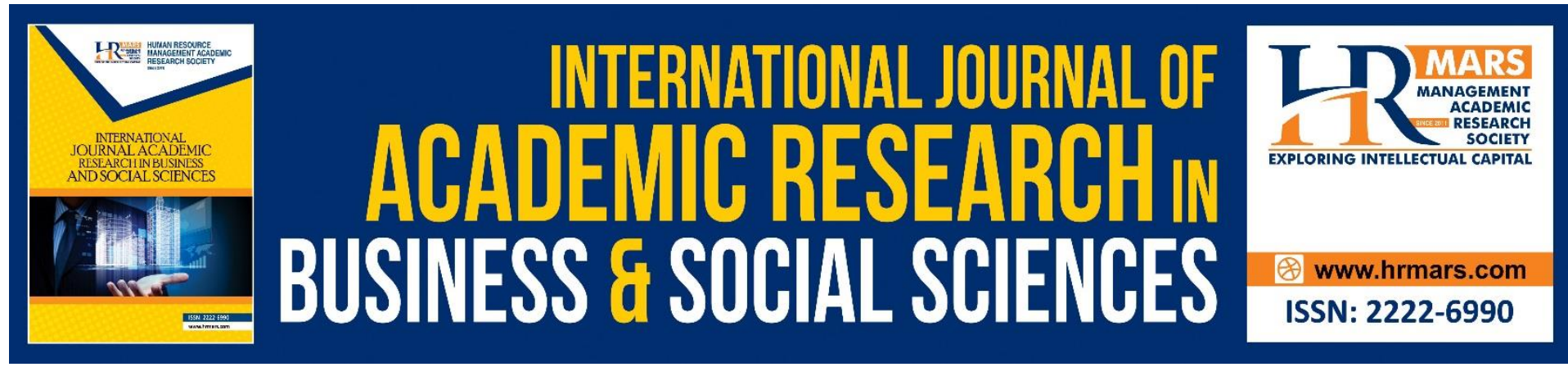

\title{
Gold Reselling in Online Transaction: A Study from Muamalat Perspective
}

\section{Muhammad Saiful Islam Ismail ${ }^{1}$, Syaimak Ismail ${ }^{2}$, Aemy Aziz ${ }^{3}$, Muhammad Anas Ibrahim ${ }^{4}$, \& Mohd Khairi Ismail ${ }^{5}$}

${ }^{1}$ Senior Lecturer, Academy of Contemporary Islamic Studies, Universiti Teknologi Mara (UiTM), Sungai Petani, Kedah, Malaysia, ${ }^{2}$ Senior Lecturer, Academy of Contemporary Islamic Studies, Universiti Teknologi Mara (UiTM), Segamat, Johor, Malaysia, ${ }^{3}$ Lecturer, Academy of

Contemporary Islamic Studies, Universiti Teknologi Mara (UiTM), Samarahan, Sarawak, Malaysia, ${ }^{4}$ Senior Lecturer, Academy of Contemporary Islamic Studies, Universiti Teknologi

Mara (UiTM), Dungun, Terengganu, Malaysia, ${ }^{5}$ Senior Lecturer, Faculty Business and Management, Universiti Teknologi Mara (UiTM), Dungun, Terengganu, Malaysia.

\begin{abstract}
Gold is promoted largely as purchasing and selling physical valuable item in Malaysia. It is importantly become a saving tools as well as for investment purpose to the society. Henceforth, many of gold's company such as Public Gold, Dinar Emas Kelantan, and others grab this kind of opportunity to offers the valuable gold item in order to attract the customer's intentness. One of the companies' marketing strategy is by issuing gold special edition such as Black Panther Wakanda Forever, Covid-19 Special Edition, and Dinar Emas Legasi TG Nik Aziz, Appreciation to Malaysia $8^{\text {th }}$ Prime Minister and others. This special offer initially caught an attention among gold reseller or collector since it may able to raise a mark-up profit by reselling this gold bar to the buyer. Besides, the lock price system also initiated in gold transaction among reseller and buyer involved the divergent among Islamic scholar poit of view. Henceforth, this article aims to explain legal consequences in reselling gold from Muamalat Perspective. This article employed inductive and deductive method by understanding from Quran, hadith, as well as Islamic school of thought as references. It is expected to contribute in exploring the concept of reselling gold transaction from Islamic law transaction which is clearly aims to avoid the element of gharar, and riba. This article suggest the policy maker such as National Fatwa Council or Shariah Advisory Council (SAC) Bank Negara Malaysia to develop a guideline or parameter regarding gold reselling standard.
\end{abstract}

Keywords: Gold Reselling, Mark-Up, Lock Price, Muamalat Perspective.

\section{Introduction}

Gold has become one of the longest historic investment activities as monetary instruments since 500 BC (World Gold Council, 2011). The aim for the transaction of selling and buying gold is to keep the people grow their wealth and sustained social status by acquired it by savings or investment purpose (Noor, 2017; Nadhirah, Rahimah, Siti Khatijah, Kasimah, \& Zainun, 2015). The previous practice of gold transition is limited to buying and selling or using 
system barter for exchange. However, the scenario has change when people nowadays start to invest in gold monetary tools as a physical collection item (Nadhirah, Rahimah, Siti Khatijah, Kasimah, \& Zainun, 2015). In Malaysia, a recent marketing trend is booming since well-known companies introduced gold bar product special edition as illustrated in Figure 1.
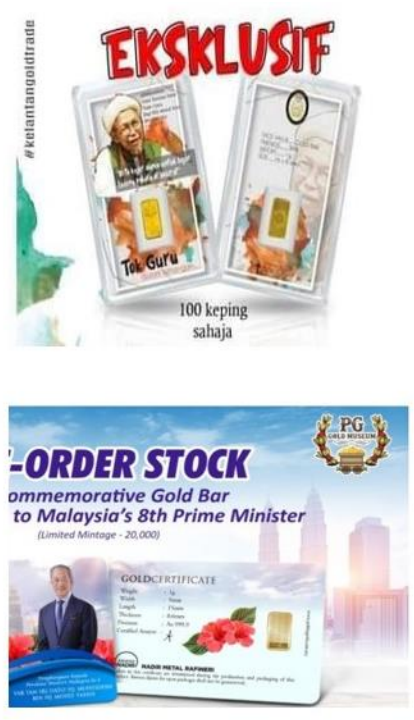

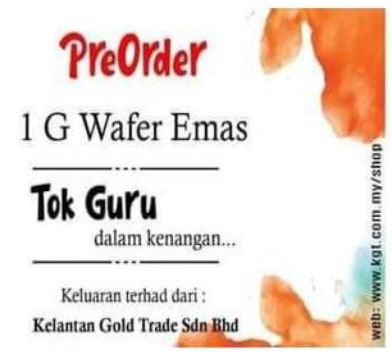

LBMA BUIIION Bar PG Ig IAL

Malaysia's 8th Prime Minis design square, celebratio collection, gift, saving Jor 999.9 纯金)

RM 1,625.00 / Per Item
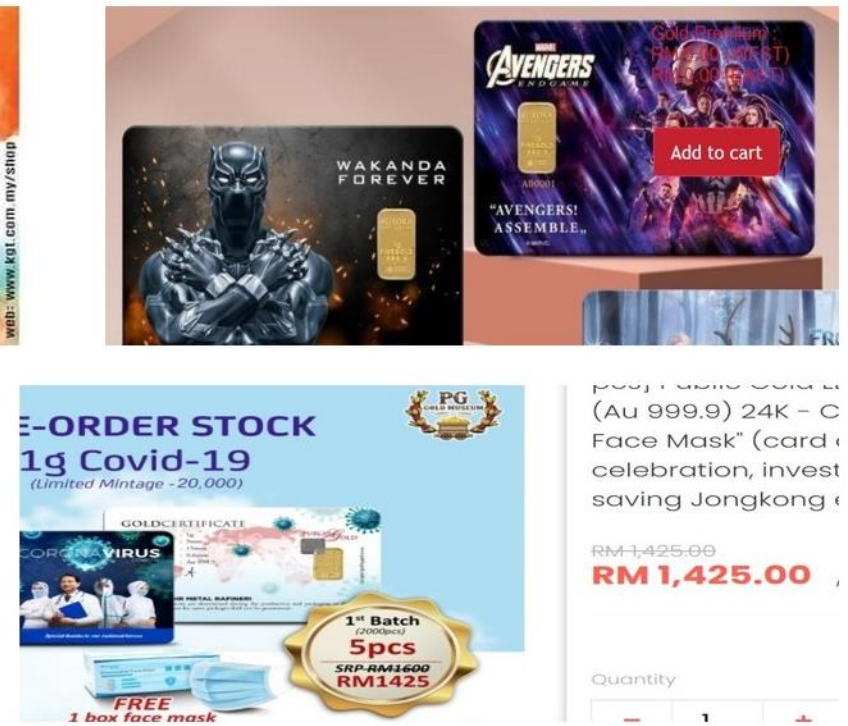

(Au 999.9) $24 K-C$ Face Mask" (card. celebration, invest saving Jongkong

RM 1,425.00

Figure 1: 1 gram gold bar special edition from Joombest, 2020; Public Gold, 2020

This kind of the product caught the attention among the gold collector due to its remarkable design and unique serial number such as Public Gold's Black Panther Wakanda Forever, Covid19 Special Edition, Dinar Emas Legasi TG Nik Aziz, Appreciation to Malaysia $8^{\text {th }}$ Prime Minister and so on (Joombest, 2020; Public Gold, 2020). For gold collectors, this is an opportunity to raise a profit by reselling back to the interested buyer. Therefore, this article aims to explain legal consequences in reselling gold focusing on mark up from Muamalat perspective since it falls under ribawi item which is obviously against in Islam.

\section{Research Methodolgy}

This article employed qualitative method in order to understand the nature of study inductively and deductively. It started with understanding the concept of gold that required the sources to fulfil the trustworthiness of data. The main sources for this research are firstly, the verses from Quran are from Holy Ouran KSU (King Saudi University) (www. http://quran.ksu.edu.sa). The translation from Arabic to English verse from Sahih International translation. Secondly, hadith sources such as Syarah Sahih Muslim (Imam AnNawawi), Sunan Abu Daud, Nasai', and Ibn Majah were referred.

Thirdly, other references include books on figh sources such as Ibn Ruysd (Bidayatul Mujtahid), al-Ba'li (Istithmar wa al-Raqabat al-Shar'iyyah: fi al-Banuk wa al-Mu'assasat alMaliyyah al-Islamiyyah) and Fiqh Islami wa Adilatuhu (Wahbah Zuhaili) were used. Those books sources assist employed to diversify and understand the transaction that was generated. Lastly, additional sources such as article online journals sources in order to understand the concept of gold from Islamic perspective. 


\section{Gold Transaction in Islamic Point of View}

Gold is considered to be a very precious item in Islam. There are several verses in Al-Quran where Allah (s.w.t) indicated the gold in human life, as well as the other things relating to gold and its function in human life. One of the verse Al-Quran, Ali Imran: 91

Indeed, those who disbelieve and die while they are disbeliever- never would the (whole) capacity of the earth in gold be accepted from one of them if he would (seek to) ransom himself with it. For those there will be a painful punishment, and they will have no helper.

(Al-Quran. Ali-Imran: 91)

The verses given above are a form of recognition from Allah SWT to gold as a most precious object on earth. In that verse Allah tries to remind us that the non-Muslim (Al-Kafirun) will never escape the retribution that Allah has set for them. And if they are able to pay for gold where the sum of gold is full of earth, they will never avoid the punishment of Allah.

Allah SWT chooses to use gold as a reference because of the place and importance of gold in human beings, and does not use other goods as a comparison, such as property, farm, fruit or animal, because if these things are comparable to gold, they will never be more or at least equal to gold. This is one of the wisdoms of the Quran that challenges and weakens all who reject Allah. Thus Allah even make gold as one of the rewards of the numerous rewards planned by Allah in Heaven for those who obey what Allah wishes/want. This matter can be known from the verses in Quran as follow:

"Those will have gardens of perpetual residence; beneath them rivers will flow. They will be adorned therein with bracelets of gold and will wear green garments of fine silk and brocade, reclining therein on adorned couches. Excellent is the reward, and good is the resting place".

(Al-Quran. Al-Kahfi: 31)

Under the Sharia regulation, gold is deemed to be one of the items and goods specifically referred to by Prophet Muhammad (S.A.W) as Ribawi. These laws and regulations (hukum) are taken from the two hadiths of Prophet Muhammad (S.A.W) as follows:

Narrated Abu Bakra: Allah's Messenger said, "Don't sell gold for gold unless equal in weight, nor silver for silver unless equal in weight, but you could sell gold for silver or silver for gold as you like."

(Sahih al-Bukhari, 2175; Sahih)

Abd al-Rabman b. Abia Bakra reported on the authority of his father that Allah's Messenger forbade the sale of gold for gold, and silver for silver except equal for equal, and commanded us to buy silver for gold as we desired and buy gold for silver as we desired. A person asked him (about the nature of payment), whereupon he said: It is to be made on the spot. This is what I heard (from Allah's Messenger (May peace be upon him).

(Sahih Muslim, 22, 112; Sahih)

Muamalat law point of view, gold transaction identified as bay' sarf. Bay' sarf is defined literally as sale purchase of money for money including gold and silver. Technically, bay' sarf is sale of money for money such as the sale of gold for gold or silver for silver (Bugha, 1992). 
According to Maliki scholars, gold transaction is the sale of price for price and each price is a consideration for the others (Zuhaili, 2007).

The discussion among Islamic scholars unanimously agree on the permissibility of bay' al sarf as it has been practiced by the people since the time of Prophet (s.a.w) until now without any objections (Zuhaili, 2007). However, the transaction of gold must be carefully practice since it falls under riba al buyu' (riba in sales). It is due to the nature being a currency fluctuate, and the condition for trading it are similar to exchanging the ribawi items. As quoted by Ubadah bin al-Samit in the hadith;

The Prophet said: "Gold for gold, silver for silver, wheat for wheat, barley for barley, dates for dates, and salt for salt - like for like, equal for equal, and hand-to-hand; if these goods differ, then you may sell as you wish, provided that the exchange is hand-to-hand."

(Sahih Muslim, no.96: Sahih)

According to some Shafie scholars, there are three conditions in selling gold transaction: a) Tamathul is must be in the same weight or value if gold is exchanged with gold or silver with silver. For currency, Ringgit with Ringgit, it should be at the same value, b) Hulul is the exchange must be immediately in cash, not in the form of credit or khiyar (cooling off period), c) Taqabudh is the exchange and delivery of good and price must be immediate in the aqad session (Bugha, 1992). Henceforth, the discussion regards with gold reselling is under the condition of tamathul taqabudh, and hulul which is explained below.

\section{Gold Reselling in Condition of Tamathul}

As mentioned above, the condition of tamathul (same value) originally referred to current world gold market (Noor, 2017). Initially, it is permissible to sell gold with mark-up price based on hire cost (Mohamad \& Salleh, 2008). However, the issue raises when the gold collector selling with acquire the profit without effort based. In other words, selling the price of gold only either under mark-up sales bay' murabahah or musawabah transaction to the buyer.

The question arise is it considered riba due to mark-up price since gold commodity knowing as ribawi item? Therefore, this article identified the divergent among Islamic scholars in regards with mark-up profit in gold transaction that consist of two point of view; 1) prohibition to mark-up sale in gold transaction and 2) permissibility to raise a profit in gold transaction. Firstly, the prohibition is based on hadith Abu Daud (2009) no. 3503 and Nasai no. 4507 means;

"It is not halal to combine debt and sale, nor two conditions in on trading, nor profit without risk, and cannot trade in non-owned goods."

(Abu Daud, 3503: Sahih)

"The profit returns in exchange for the risk he bears."

(Nasai', 4507: Hasan)

The hadith above mentioned profit without risk means the profit acquire without any effort to acquire the product (Al-Khattab, 2007). In fact, the profit returns are based on the risk that the seller bears (Al-Khattab, 2008). Back to the issue, the gold collector resale the gold bar special edition which is not based on his effort, the reason behind mark-up price is because 
of authentic design, special serial number and others, unless, the seller take a profit on hire basis for the maintenance, transportation, or advertisement fees is still permissible. If not, this kind of transaction falls under riba basis cause of ribawi item. As defined riba is an excess stipulated as an obligatory condition on one of parties (Ibn Rusyd, 2003). In Quran stated the prohibition of riba:

"O you who believe! Do not take riba doubled and multiplied, but fear Allah so that you may be successful"

(Al-Imran: 130)

In fact, Ibn Rusyd (2003) and al-Ba'li (1991) described one of condition of murabahah sale purchase must not include ribawi item. Therefore, it is necessarily the gold reseller transparent the information in avoiding gharar due to mark-up profit must according to hire cost definitely. As mentioned in hadith below;

"When there are different types of goods (sold and purchased) that is not ribawi goods, then you can trade as you wish (in terms of price difference or cash or differed)"

(Ibn Majah, no.2289)

Secondly, the permissibility to trade gold by mark-up the profit is based on the opinion by Shafi' and Maliki scholars (Zuhaili, 2007). It is because gold is no longer functional as medium of exchange, but it is considered as a commodity (Bugha, 1992; Zuhaili, 2007). In addition, the hadith as mentioned above quoted by Ubadah bin al-Samit describes the hukm of sale contract/exchange of ribawi items involved with barter exchange only (Noor, 2017).

It does not put the condition of riba al-buyu' for a normal sale contract such buying rice or gold with money (Noor, 2017). Therefore, gold is a product purchase which permissible to increase mark-up sales as long as it fulfils the conditions as mentioned above. The scholars have agreed that the contract includes all types of gold and silver whether they have different quality, completeness and pureness must be on same value and weight (Ba'li, 1991; Noor, 2017). As reported by Imam An-Nawawi (1981);

Rasullullah S.A.W. has said: "Do not transact gold with gold or silver with silver except in the same value..."

(Sahih Muslim, no. 195: Sahih)

In addition, other justification the permissibility of gold reselling transaction by mutual consent is based on Al-Qur'an;

"O you who believe! Eat not up your property among yourselves in vanity, but let there be among you trade by mutual consent...

(Al-Qur'an, al- Nisa':29)

Zuhaili (2007) emphasized that it is unlawful to take the property of a Muslim except by his consent. However, neither the Qur'an nor the Prophet explained how mutual consent should be ascertained. This task was concluded by the jurists that must be consent in all intangible mental fact (which has to be manifested before its existence could be known). Before it is so 
manifested, it is a mere intention (niyyah) not sufficiently to conclude the contract (Zuhaili, 2007). Therefore, the permissibility to resale gold bar special edition should fulfil this criterion by transpiring the intention of gold reseller with information has given to the buyer in order to avoid misrepresentation (ghabn) and uncertainty (gharar) circumstances.

\section{Gold Reselling in Condition of Hulul and Taqabudh}

Transactions involving ribawi items have a specific feature referring to the hadith of the Prophet Muhammad SAW. For instance, the transaction involving the exchange of the same type as gold for gold must be taqabudh fi al-majlis (on the spot exchange transaction in one session) and hulul (no delay). In this circumstance, the common issue might be raised whether it is permissible to purchase gold via online transaction. This is because, it may falls under the prohibition of ribawi item that clearly against the muamalat law due to on the spot transaction. Since the condition of hulul and taqabudh is complying by on the spot or hand to hand transaction, nevertheless, in current practice, the sale purchase of gold has employed the method of "lock price".

The "lock price" is a popular method especially in physical gold transactions. The value of gold in the market is constantly changing in $\mathbf{2 0}$ minutes, given that this method gives customers the advantage of locking the price at a lower level at a time before receiving physical gold (Mohamed \& Saleh, 2008). Initially, the gold reseller practiced this kind of principles in order to resell his gold collection item to the buyer. However, this method is related to the deferred issue of the physical gold transaction due to the transaction period that occurs after "lock price." This method can be linked to the concept of waad (promises) as condition in the context of bookings and hedging the transactions. In other words, the buyer promise to pay first the gold on lock price, later the seller will delivered by postage.

As mentioned on hadith above, the transaction is cannot be postponed and there must be a submission by both parties in one session. In the form of promises (waad) to purchase gold event if there is a khiyar syart (option of condition) in the transaction then the majority of the scholars (Shafi'I, Maliki, and Hanafi) except Hanbali stated the contract of the transaction is void (al-Kasani 2010). The Hanbali school of thought considered the condition of khiyar in the gold transaction is still valid, but not binding (ghair lazim) the promises. If the gold seller tend to penalize buyer in the event of default (break the promise to purchase), the condition of khiyar is void (Ibn Qudamah, 1997).

This is because the khiyar makes the transaction contract still not binding (ghair lazim) as if there is a period of time based on the conditions of deferment in the transaction contract. Hence, the prohibition of delay in the transaction of ribawi items through the hadith of the Prophet Muhammad SAW:

Yahya related to me from Malik from Nafi from Abdullah ibn Umar that Umar ibn al-Khattab said, "Do not sell gold for gold except like for like, and do not increase one part over another part. Do not sell silver for silver except like for like, and do not increase one part over another part. Do not sell silver for gold, one of them at hand and the other to be given later. If someone seeks to delay paying you until he has been to his house, do not leave him. I fear rama for you." Rama is usury.

(Muwatta' Malik: 31; 34) 
These justifications leads into the prohibition of gold transaction in term of deferred gold delivery to the customers, specifically in the condition waad, taqabudh, and hulul. Henceforth, the reseller must deliver the item (on current gold price) hand to hand in order to avoid these prohibitions as mentioned above.

\section{Conclusion and Recommendation}

Reselling gold transaction is a crucial issue since it involved with ribawi item. It is considered as riba al-buyu' that against Islamic law transaction (Muamalat). Based on the justification above in the condition of tamathul, the gold reseller must be alert with the transaction has been made by exposing their true intention, and disclosing the mark-up price according to hire cost such as maintenance, transportation, and advertisement fee to the buyer. From researchers' point of view, mark-up based on special design and unique serial number still remain elusive in terms of information value added of product.

In the meantime, the reseller also compulsory to fulfil these conditions such as hulul, taqabudh and waad during the majlis al- aqad (single session). This means, the delivery of gold must be hand to hand and the price should be mentioned transparently. These conditions can help the transaction to be free from the element of riba, gharar, and misrepresentation of pricing (ghabn) which against the muamalat principles. Furthermore, this article recommend the policy maker such as National Fatwa Council or Shariah Advisory Council (SAC) Bank Negara Malaysia to develop a guideline or parameter regarding gold reselling standard. As the outcome, this parameter able to increase level of knowledge and awareness among the Muslim society in relation with the transaction of gold reselling that complying with the Sharia rulings and achieve His mardhatillah in world and hereafter.

\section{References}

Al-Andalusi, Y. Y.-L. (2000). The Muwatta of Imam Malik. Karachi: Darul Ishaat.

Al-Khattab, N. (2007). Sunan An-Nasa'i. Riyadh: Darussalam.

Al-Khattab, N. (2008). Sunan Abu Daud. Riyadh, Saudi: Darussalam.

An-Nawawi. (1981). Sahih Muslim Bi Syarh al-Nawawi. Qaherah: Dar al-Fikr.

Ba'li, A. H. M. (1991), Al-Istithmar wa al-Raqabat al-Shar'iyyah: fi al-Banuk wa alMu'assasat al-Maliyyah al-Islamiyyah: Dirasat Fiqhiyyah wa Qanuniyyah wa Masrafiyyah. Kaherah: Bank Faisal al-Islami.

Bugha, M. (1992). Al-Fiqh al-Manhaji. Dar al-Qalam.

Ibn Rushd, M. A. (2003). Bidayat al-Mujtahid wa Nihayat al-Muqtasid. al-Qahirah: Dar alHadith.

Joombest. (2020). Eksklusif Tok Guru; Ulama Sepanjang Zaman. Retrieved from Portal Kelantan Gold Trade Sdn. Bhd.: https://kgt.com.my/KGT2016/

Mohamad, S., \& Salleh, S. (2008). Upah simpan barang dalam skim ar-rahnu: Satu penilaian semula. Jurnal Fiqh, 5, 47-65. https://fiqh.um.edu.my/article/view/4183/2032

Nadhirah, N., Rahimah, E., Siti Khatijah, I., Kasimah, K., \& Zainun, M. (2015), Shariah compliant gold investment: An understanding among academicians in Terengganu, Malaysia. International Journal of Academic Research in Business and Social Sciences, 8(10), 226235. http://dx.doi.org/10.6007/IJARBSS/v8-i10/4728 DOI: 10.6007/IJARBSS/v8i10/4728.

Noor, A. M. (2017). Shariah issues in gold trading and gold related schemes. Alshajarah. (Special Issue IIBF), 61-84. 
Public Gold. (2020). Public Gold Powered by Oracle. Retrieved from Public Gold: https://publicgold.com.my/index.php/products?task=DisplayGold

Qudamah, I. (1997). Al-Mughni. Beirut: Dar' Alam al Kutub.

World Gold Council. (2011). Liquidity in the Global Market. London: World Gold Council Publisher.

Zuhaili, W. (2007). Fiqhul Islami Wa Adilatuh. Beirut: Darul Fikr. 